\title{
Teleost Metamorphosis: The Role of Thyroid Hormone
}

\author{
Marco António Campinho* \\ Centre for Marine Sciences (CCMAR), Faro, Portugal
}

In most teleosts, metamorphosis encompasses a dramatic post-natal developmental process where the free-swimming larvae undergo a series of morphological, cellular and physiological changes that enable the larvae to become a fully formed, albeit sexually immature, juvenile fish. In all teleosts studied to date thyroid hormones (TH) drive metamorphosis, being the necessary and sufficient factors behind this developmental transition. During metamorphosis, negative regulation of thyrotropin by thyroxine (T4) is

OPEN ACCESS

Edited by:

Frédéric Flamant, École Normale Supérieure de

Lyon, France

Reviewed by:

Hector Escriva,

Centre National de la Recherche

Scientifique (CNRS), France

Guillaume Holzer,

University Hospital RWTH

Aachen, Germany

${ }^{*}$ Correspondence:

Marco António Campinho

macampinho@ualg.pt

Specialty section:

This article was submitted to

Thyroid Endocrinology,

a section of the journal

Frontiers in Endocrinology

Received: 17 January 2019

Accepted: 28 May 2019

Published: 14 June 2019

Citation:

Campinho MA (2019) Teleost Metamorphosis: The Role of Thyroid Hormone. Front. Endocrinol. 10:383.

doi: 10.3389/fendo.2019.00383 relaxed allowing higher whole-body levels of T4 that enable specific responses at the tissue/cellular level. Higher local thyroid cellular signaling leads to cell-specific responses that bring about localized developmental events. TH orchestrate in a spatial-temporal manner all local developmental changes so that in the end a fully functional organism arises. In bilateral teleost species, the most evident metamorphic morphological change underlies a transition to a more streamlined body. In the pleuronectiform lineage (flatfishes), these metamorphic morphological changes are more dramatic. The most evident is the migration of one eye to the opposite side of the head and the symmetric pelagic larva development into an asymmetric benthic juvenile. This transition encompasses a dramatic loss of the embryonic derived dorsal-ventral and left-right axis. The embryonic dorsal-ventral axis becomes the left-right axis, whereas the embryonic left-right axis becomes, irrespectively, the dorsal-ventral axis of the juvenile animal. This event is an unparalleled morphological change in vertebrate development and a remarkable display of the capacity of $\mathrm{TH}$-signaling in shaping adaptation and evolution in teleosts. Notwithstanding all this knowledge, there are still fundamental questions in teleost metamorphosis left unanswered: how the central regulation of metamorphosis is achieved and the neuroendocrine network involved is unclear; the detailed cellular and molecular events that give rise to the developmental processes occurring during teleost metamorphosis are still mostly unknown. Also in flatfish, comparatively little is still known about the developmental processes behind asymmetric development. This review summarizes the current knowledge on teleost metamorphosis and explores the gaps that still need to be challenged.

Keywords: thyroid hormones, metamorphosis, teleost, morphogenesis, asymmetry 


\section{INTRODUCTION}

Teleosts (ray-finned fish) constitute the most diversified vertebrate group (1). They comprise more than 23,000 species and occupy a wide range of aquatic habitats, morphologies, behavior, and physiology. Most teleosts develop indirectly, i.e., between the end of embryonic development and sexually immature juvenile stages, they assume a transitional larval form where rudiments of all organs are already present, although not mature. Also, teleost larvae can present different ecologies and physiologies from their adult form.

It is only at the transition from larvae to juvenile that the metamorphosis occurs, and where the larva develops into a fully formed fish identical to the adult form but still sexually immature. In most teleosts, with both symmetric and asymmetric morphologies, this developmental transition is orchestrated by thyroid hormones $(\mathrm{TH})$ that are the sufficient factors necessary for larvae to undergo metamorphosis. Production of TH occurs in the thyroid gland and consists of the prohormone thyroxine (T4) and the active hormone triiodothyronine (T3). Conversion, transport, and binding of $\mathrm{T} 3$ to its cognate receptors are tightly regulated at the cellular level since $\mathrm{TH}$ needs to be in a strict physiological range (2).

The involvement and dependence of $\mathrm{TH}$ for teleost metamorphosis were initially found in flatfish (3-15). Later it was also found that in most symmetric teleost species, metamorphosis occurs and parallels the developmental landmarks seen in flatfishes. The pre-metamorphic stage is characterized by lower whole-body levels of T4 and T3 and lower expression of thyrotropin ( $\mathrm{tsh} b)$, thyroglobulin ( $\mathrm{tg})$, deiodinase 2 (dio2), and thyroid hormone receptor beta (thrb) and higher expression of deiodinase 3 (dio3) (Figure 1). As soon as metamorphosis started, T4 and T3 increase together with increased expression of $t h s b$, $t g, t h r b$, and dio 2 and decreased dio 3 expression (Figure 1). The levels of T4 and T3 and expression of $t s h b, t g, t h r b$, dio2 peak at the climax of metamorphosis, whereas dio3 expression attains its lowest expression levels (Figure 1). As metamorphosis terminates the levels of T4 and T3 and markers of gene expression return to pre-metamorphic levels (15-24) (Figure 1). So far the observed markers and stages of metamorphosis are conserved between teleosts and anurans, clearly showing that this is a homologous developmental process regulated by $\mathrm{TH}$ (Figure $\mathbf{1}$ ).

The evidence today points to $\mathrm{TH}$ regulation of most organ maturation and developmental processes that occur during teleost metamorphosis. These changes enable not only a more efficient locomotion and digestion but also physiological and metabolic adaptations that allow the juvenile fish to adapt to their new habitat and lifestyle.

\section{CENTRAL REGULATION OF METAMORPHOSIS}

One of the outstanding characteristics of anuran and teleost metamorphosis, in comparison to other developmental events,

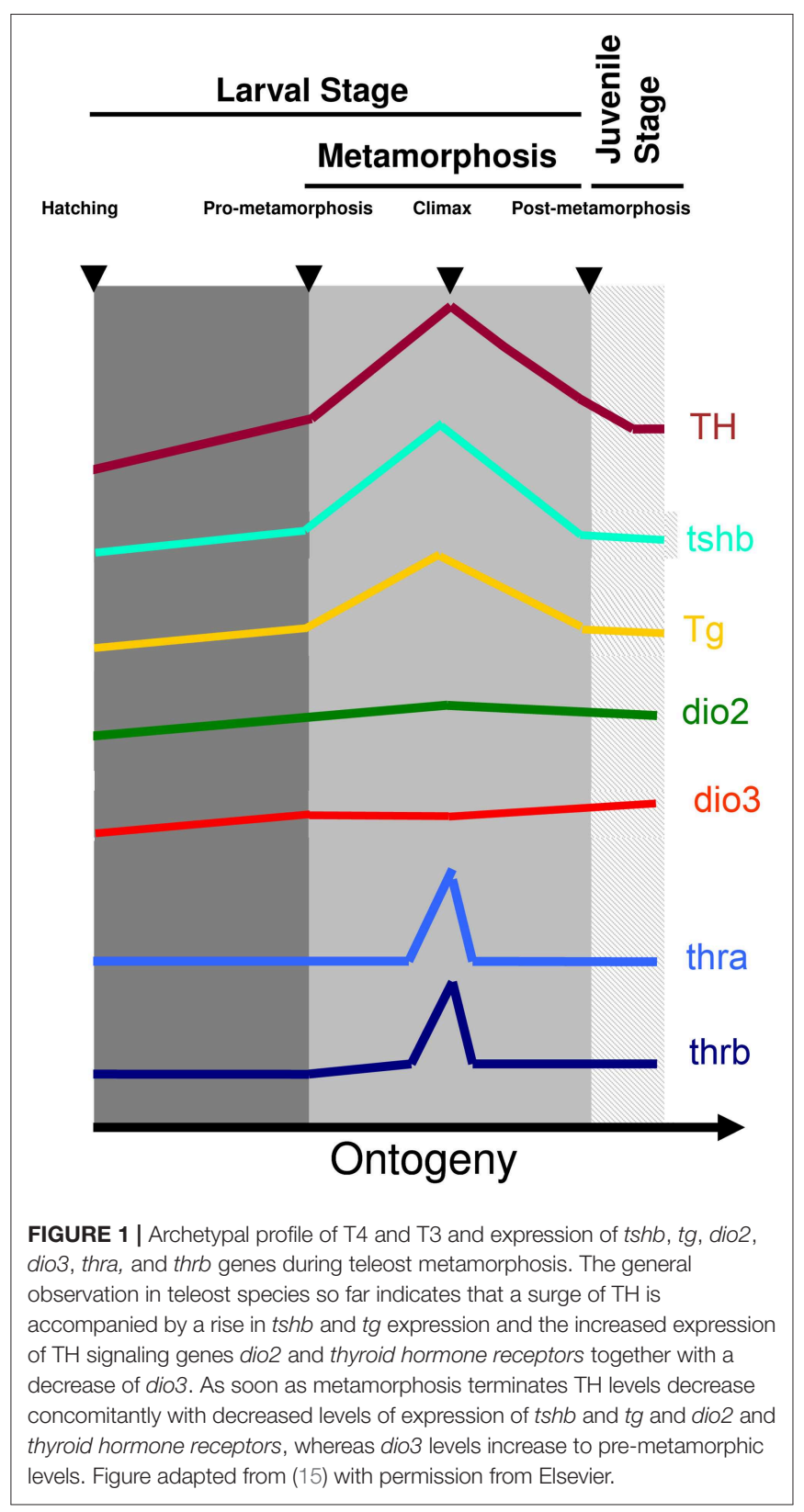

is the existence of a central regulation at the organismal level together with organ/tissue/cell-specific regulation of $\mathrm{TH}$ signaling. This regulation enables metamorphosis to occur when appropriate environmental conditions are achieved. A better example remains unknown where the factor that regulates each developmental event is also regulated at the central organismal level so that increased serum concentration can drive specific cellular developmental events.

Given the importance of $\mathrm{TH}$ in the regulation of a wide range of molecular pathways, their production by the thyroid gland is tightly controlled by the hypothalamic-pituitary-thyroid (HPT) axis, which ensures homeostasis of TH serum levels. This serum TH homeostasis is achieved in different ways in vertebrates 
so far studied. In adult mammals, hypothalamic thyrotropinreleasing hormone (TRH) is released into the hypophyseal portal system and regulates the production of thyrotropin (TSHb) by the pituitary gland, that in turn regulates $\mathrm{TH}$ production by the thyroid gland (25). In adult reptiles and birds, the hypothalamic factor, corticotropin-releasing hormone $(\mathrm{CRH})$, has a more prominent role in regulating thyrotropin (TSHb) secretion and T4 serum levels than TRH $(26,27)$. However, in teleosts, the current knowledge suggests species-specific regulation of the HPT axis (28-34). The observation that in adult cyprinids, Leptin, Galanin, $\beta$-endorphin, and neuropeptide Y (NPY) can regulate in vitro pituitary tshb expression (Figure 2), suggests that in teleosts pituitary-thyroid regulation may occur by hypothalamic factor/s other than TRH or CRH or by other, non-hypothalamic, endocrine factors (34) (Figure 2). Some studies in teleosts suggest that hypothalamic inhibition rather than stimulation by an unidentified factor might constitute the primary mechanism for HPT-axis regulation (35-37). In flatfish, even considering the known involvement of $\mathrm{TH}$ in metamorphosis, the knowledge on the regulation of the HPTaxis and the underlying neuroendocrine regulation remains very scarce.

During post-embryonic development, $\mathrm{TH}$ are the necessary and essential factors regulating metamorphosis. TH exerts their effect through a whole-body and tissue/cell-specific manner, both in anurans and flatfishes $(3-5,27,28,38,39)$. In metamorphosing anurans, the central regulation of metamorphosis involves both the hypothalamic-pituitary-thyroid (HPT) axis and the hypothalamus-pituitary-adrenal gland axis (HPA), more commonly associated with stress (Figure 2). Environmental cues, such as decreased water levels, stimulate the HPA axis, and the release of $\mathrm{CRH}$, which acts via its receptor, $\mathrm{CRHr}$ 2, in pituitary thyrotrophs to enhance $\mathrm{TSHb}$ secretion, $\mathrm{TH}$ production and triggering metamorphosis [revised in (27); Figure 2]. A common feature of anurans and flatfishes is the simultaneous increase in tshb expression and $\mathrm{TH}$ serum levels during metamorphosis. In anuran metamorphosis, the set-point of the HPT axis is modulated by the action of $\mathrm{CRH}$ on pituitary thyrotrophs, so that high levels of serum $\mathrm{TH}$ do not repress $t s h b$ expression [revised in (27)]. In adult teleosts and during metamorphosis, TH are the main regulators of pituitary $t s h b$ expression, pointing to a central negative feedback mechanism at the level of the pituitary and the thyroid gland $(28,31,32,34,40,41)$ (Figure 2). During flatfish metamorphosis, hypothalamic inhibition is relieved, and the negative feedback on pituitary tshb by plasma $\mathrm{TH}$ adjusts to a higher set-point $(28,30,41)$. Goitrogens block sole (Solea senegalensis) metamorphosis, indicating that the negative feedback loop between the thyroid and the pituitary gland is functional in larvae well before metamorphosis $(28,41,42)$. Evidence on how the flatfish hypothalamus regulates the HPTaxis remains elusive. Recent work on flatfish metamorphosis, suggests that hypothalamic thyrotroph regulation may not exist at all during sole metamorphosis (41) (Figure 2). In sole larvae, blocking of metamorphosis after methimazole treatment (that blocks iodination of $\mathrm{Tg}$ and $\mathrm{T} 4$ production) did not change the temporal and spatial expression of trh and $c r h$, suggesting that these neuroendocrine factors are not involved in sole metamorphosis. As a whole, the evidence raises fundamental questions about hypothalamic regulation of $\mathrm{TH}$ during metamorphic development in teleosts. The way tshb expression is regulated to induce metamorphosis of symmetric teleosts is even less well-known, and a great gap of knowledge exists on how the onset of metamorphosis occurs in these teleosts. It is still one of the great open questions in teleost metamorphosis.

Collectively, these evidences highlight a conserved mode of action in teleosts and an integrated response of the larval organism to the signal of TH. First, tshb level increases whole organism $\mathrm{TH}$ content that in turn gives rise to local tissue/cell responses. These are mediated locally by dio 2 and dio3 ratios (discussed below) and increased thrb expression that allows the initiation of the metamorphic program and the morphogenetic changes in sensitive tissues. As in anurans, in teleost, metamorphosis thrb is considered to be the major TH receptor mediating metamorphic cell responses. However, there is little to none functional evidence in teleosts to support this view. This consideration derives from evidence in anurans [revised in (27)] and the existence, by whole-body analysis, of a peak in expression of thrb at the climax of metamorphosis in several teleosts $(13-16,43,44)$. Since in most teleost species there are at least three different $\mathrm{TH}$ receptor genes (thraa, thrab, and thrb), it is likely that different $T H$ receptors are involved in specific metamorphic events. The most likely scenario is that in some cells/tissues, metamorphic morphogenetic events are regulated by thraa, thrab, or thrb or even a combination of all or some $\mathrm{TH}$ receptors in a given cell/tissue. Nonetheless, in sole metamorphosis, the asymmetric development of the pseudomesial bone (discussed below) is correlated only with the asymmetric expression of thrb, strongly suggesting that, at least for this metamorphic event, thrb is the main effector of $\mathrm{TH}$ function (45). The actual scenario on the TH receptors mediating each metamorphic event is not clear and more work is necessary to elucidate this question in teleost metamorphosis.

\section{MORPHOLOGICAL, MORPHOGENETIC, AND PHYSIOLOGICAL CHANGES DURING TELEOST METAMORPHOSIS}

The word metamorphosis derives from the ancient Greek, where it means a change in form. In teleosts, just as in anurans, the larvae undergo such morphological changes that the overall shape of the animal gives rise to the juvenile form. In flatfish, this developmental event results in a dramatic morphological change. The symmetric flatfish larva develops into an asymmetric juvenile that is characterized by the migration of one eye to the opposite side of the head and the tilting of the body axis toward the migrating eye side. In the end, the primary body axis changes with regards to the original embryonic established dorsal-ventral and left-right axis (LRA). The lateral ocular side becomes dorsal, the blind lateral side becomes ventral, and the dorsal and ventral sides become left or right. The metamorphosed flatfish juvenile becomes a benthic animal in contrast to the pelagic larvae from which it arises. Its form adapts perfectly to life in the bottom of 

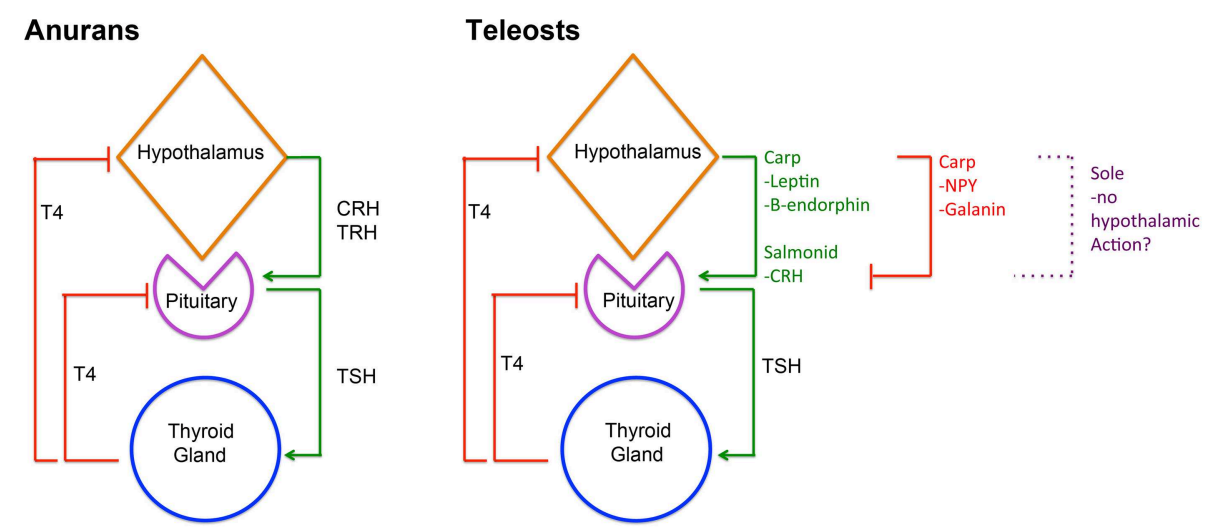

FIGURE 2 | Diagram depicting HPT-axis regulation in anurans and teleosts. In anurans, hypothalamic derived $\mathrm{CRH}$ and/or TRH are involved in regulating pituitary $\mathrm{TSHb}$ expression and secretion that in turn regulates T4 production in the thyroid gland and consequently serum levels. Inversely, serum T4 then negatively regulates $\mathrm{CRH} / \mathrm{TRH}$ and TSHb expression and secretion. In teleosts, HPT-axis regulation is more diverse and likely reflects species specificity. In salmonids, CRH seems to regulate pituitary TSHb expression and secretion, whereas in carp leptin and $\beta$-endorphin seem to assume that role. Notably, in carp, Galanin, and NPY seem to repress TSHb expression and secretion. Remarkably, in sole metamorphosis, neither TRH nor $\mathrm{CRH}$ seems to be involved in regulating pituitary TSHb raising questions about the role of the hypothalamus in HPT-axis regulation in these teleosts. Despite this, in all teleosts studied so far, the negative feedback loop between thyroid gland T4 and pituitary TSHb is present and conserved.

aquatic environments where it uses stealth to prey and escape predators. The morphogenetic changes in symmetric teleosts are more subtle and do not change the embryonic derived body axis of the animal.

Nonetheless, in both teleost groups, they render the postmetamorphic juvenile a more hydrodynamic efficient form (46-50), reducing drag and enabling faster and less energy consumption during locomotion. These hydrodynamic changes are accompanied by a change in swimming mode with a passage from a larval C-shape movement to a more S-shape movement $(48,50)$. As the larvae undergo metamorphosis, these changes preconize an adaptation of form to fit a new function/lifestyle. To enable these changes, all the major organ systems in the larvae develop in response to higher metamorphic TH-levels.

\section{AXIAL MUSCLE}

Simultaneously with the change in locomotion, TH during metamorphosis reshapes the constitution of muscle fibers and the myotome. In most teleosts studied so far, a generalized increase in muscle hyperplasia occurs in the myotomes at the start of metamorphosis, that afterwards, gives way to increased muscular hypertrophy. This shift in muscle growth is more evident in the most epa- and hypaxial regions of the myotomes of metamorphic larvae, where there is a steep increase in the number of new muscle fibers developing (5155, 55-66). During seabream (Sparus aurata) metamorphosis, several sarcomeric genes undergo isoform switching that are likely involved in modulation of locomotion (55, 55-57, 63, 64, 67). The increase in thyroid hormones during metamorphosis correlates with mRNA splicing events of troponin $T$ (tnnt) genes in S. aurata, Paralichthys olivaceus (summer flounder), Solea solea, Scophthalmus maximus (turbot), and Hyppoglossus hyppoglossus (halibut) $(59,60,68-70)$. Similar responses to T3 of other sarcomeric genes and proteins, like myosin heavy chain (71) and Ca-ATPase (72), are found in mammals. Some teleost species, during metamorphosis, develop a teleost-specific axial muscle denominated pink muscle that presents biochemical and functional characteristics intermediate of white and red muscle (54, 56, 73-76).

Notably, studies on halibut metamorphosis show that dio2 and 3 play a critical role in these muscular developmental changes. The enzymes, dio 2 and 3, are expressed in the same hyperplasic cells in the most epaxial and hypaxial regions of the myotome of early metamorphosing larvae, indicating that a tight regulation of cellular $\mathrm{TH}$ is essential for this cell proliferation. From the climax of metamorphosis onwards, the epa- and hypaxial cells co-expressing dio 2 and dio 3 become scattered throughout the myotome and resemble muscle pioneer cells (39). This evidence shows that $\mathrm{TH}$ is involved in axial muscle development during and after teleost metamorphosis. Nonetheless, more detailed studies are still needed to directly demonstrate the exact role of TH in teleost skeletal muscle development. Notably, the THdependent changes in skeletal muscle development in teleosts mirror some of the effects of TH in mammalian skeletal muscle development, where Dio2 and Dio3 activity is pivotal in the regulation of $\mathrm{TH}$-action [revised in (77)].

\section{BLOOD}

Together with locomotion changes and the joint development of axial muscle during metamorphosis, there are also changes in gas-exchange. In most teleosts, blood develops fairly soon during embryonic development $(78,79)$. However, embryonic/larval erythrocytes are not fully mature. Most of the gas-exchanges in larvae until metamorphosis occur by simple diffusion through the skin (80). It is only at metamorphosis that erythrocytes can efficiently retrieve $\mathrm{CO}_{2}$ from cells and deliver oxygen to 
the tissues. TH stimulates and promotes the switching in the expression of alpha-globin genes from larval to adult isoforms $(5,81-84)$. This switching enables a more efficient gas exchange in juvenile rainbow trout in comparison to larval animals, with greater Bohr effect in adult haemoglobins (82). During amphibian metamorphosis, there is a similar regulation of haemoglobins, and the evidence seems to suggest that this event occur so that the metamorphosed animal can adapt to the new post-metamorphic environment $(85,86)$.

Taken together, gas-exchange at the gill level becomes more prominent as metamorphosis progresses. This transition in gas-exchange is especially important since the skin becomes more complex, stratified and impermeable to gases $(80,87$, 88) as a direct consequence of $\mathrm{TH}$-driven skin development during metamorphosis.

\section{SKIN}

The skin of teleost larvae is composed only of an epidermal layer and has little or no stratification. As the larvae undergo metamorphosis, the skin develops into a stratified epithelium with a multi-layered epidermis and dermis, which is formed by an acellular layer of collagen that is invaded by fibroblasts (87-92). At the same time, the adult pigmentation pattern starts to develop (93-97). Interestingly, in flatfish pigmentation becomes asymmetric when eye migration terminates. However, melanocyte precursors cells are found symmetrically distributed in the animal, but only the ones on the ocular side differentiate into melanocytes $(95,96)$. It is still unclear how these cells respond asymmetrically to TH. In zebrafish, as metamorphosis comes to an end, scales start to develop from specialized fibroblasts that have invaded the collagen lamella (98).

In teleost skin, keratinocytes are direct targets of TH. Before metamorphosis, halibut larval keratinocytes only express dio3 but as soon as the larvae enter the climax of metamorphosis, dio2 becomes highly expressed (39). Together with this increase of dio 2 expression, keratinocytes start to lose their larval morphology, larval keratin isoforms are repressed and apparently, no epidermal keratin is expressed in adult body skin keratinocytes $(87,99,100)$. Notably, as keratinocytes differentiate toward an adult phenotype, they lose a distinct basal keratin bundle that is present only in larval cells (87).

During the much better studied amphibian metamorphosis, it is known that both cellular and molecular changes in the skin are dependent on $\mathrm{TH}$ and gave rise to fully stratified skin after metamorphosis (101-103), thus paralleling the observed events in teleost skin during metamorphosis. The most striking difference between teleost and anurans during skin metamorphic development is the apparent lack of expression of postmetamorphic keratin isoforms in teleost skin $[88,103,104]$.

Taken together, $\mathrm{TH}$ during metamorphosis gives rise to an orchestrated series of developmental events in the skin of teleosts that make this organ develop from a simple to a complex structure that is a more impermeable and selective barrier. Importantly, these changes give rise to a dramatic shift in the physiology of the larvae since gas exchanges switch from the skin to the gills (80).

\section{SKELETAL DEVELOPMENT}

In mammals, $\mathrm{TH}$ is an important factor in bone development and homeostasis [revised in (104)]. So far, this aspect of metamorphosis has not received much attention in teleosts. Teleost skeleton develops significantly during metamorphosis. During the larval stage, most cartilaginous structures are already present, but most of the dermal derived bones are still absent. Most dermal derived bones develop as metamorphosis starts, and most of the cartilaginous derived bone starts to transit from their cartilaginous scaffold into an ossified definitive structure during metamorphosis $(11,45,105-118)$.

Especially notable during metamorphosis is the development of the dermal derived structures of the axial skeleton, namely the vertebral bodies. These dermal derived structures start to ossify as soon as metamorphosis begins. Simultaneously, the neurocranium starts its ossification at this stage from the mesenchyme tissue surrounding the brain. Together with the resorption of the larvae fin-fold, the fin rays begin to develop and ossify, enabling the full development of the fins after metamorphosis $(11,105-107,110-118)$.

One interesting aspect of how skeletal development during metamorphosis can be adjusted to allow better adaptations to the habitat conditions of juveniles, comes from Oreochromis mossambicus (Mozambique tilapia). In this species rearing of metamorphosing larvae at higher temperatures promotes carnivore-oriented skull development, whereas lower temperatures reared larvae developed omnivore oriented structures (116). Although the exact role of TH signaling is unknown, these observations highlight that during tilapia metamorphosis, skeletal development is adjusted to match the specific environmental needs posed to the larvae.

However, most of the studies on the role of $\mathrm{TH}$ on teleost skeletal development are descriptive. Some reports show that changes in $\mathrm{TH}$ signaling might correlate with abnormal skeletal development in S. senegalensis (113). Also, $\mathrm{TH}$ signaling is essential for asymmetric development of the flatfish specific pseudomesial bone (45). Despite these advances, still much remains to be found about the exact role and the genetics of $\mathrm{TH}$ signaling regulating bone development during teleost metamorphosis.

\section{GASTROINTESTINAL-TRACT}

One of the key features of anuran metamorphosis is the development of the gastrointestinal (GI) tract. During metamorphosis, the tadpole gut shortens and modifies to allow a shift from herbivorous to carnivorous feeding [revised in (119)]. In mammals, $\mathrm{TH}$ is essential for the development of the gut, where Thra plays a crucial role in GI cell differentiation (120-122). During teleost metamorphosis, the larvae GI tract is also home to a series of significant morphological, molecular and functional changes (9, 123-131). In Atlantic halibut, Japanese 
flounder and summer flounder metamorphosis leads to higher compartmentalization of the GI tract. In these flatfish, the development of the stomach and an increased length, folding, and regionalization of the intestine is observed. Accompanying these morphological events is the beginning of the expression of pepsinogen $(126,129-131)$. Similar development of the GI tract is observed in the symmetrical teleost Dicentrarchus labrax (sea bass) $(124,128)$. One key feature of teleost intestine development at metamorphosis is the increase in microvilli area, globulet and secretory cells $(124,126,128,131)$. In halibut, one of the key features of metamorphic stomach development is the synchronous establishment of molecular and cellular components in such a way that stomach function starts at the climax of metamorphosis (126).

Together with the digestive tract changes, other organs involved in digestion respond to increased TH-levels during teleost metamorphosis. In the zebrafish pancreas at metamorphosis, $\beta$-cell differentiation and insulin expression increase and respond positively to exogenous $\mathrm{TH}$ treatment, whereas the opposite is observed for glucagon expression (132). In Senegalese sole, early in metamorphosis, the intestine and liver start to express apolipoprotein $A-I$ that is involved in cholesterol metabolism (133). This evidence suggests that during metamorphosis, $\mathrm{TH}$ regulates many of the developmental events in most GI-tract organs to allow a novel metabolic and homeostatic program to start and take full advantage of the novel food sources in the post-metamorphic habitat.

\section{FLATFISH METAMORPHOSIS ASYMMETRIC HEAD DEVELOPMENT}

Of all teleosts, flatfishes display the most dramatic morphological manifestation of metamorphosis. It was considered, since its discovery, that these teleosts become asymmetric at metamorphosis (134). The fossil record shows that eye migration is one of the early events taking place during flatfish metamorphic evolution $(135,136)$. Nonetheless, evidence shows that, besides skin pigmentation, asymmetric metamorphic development observed at the body level is located in the most anterior third of the head that encompasses the eye field $(11,39,45,59,87,115,117,118,137,138)$.

Evidence suggested that sub-dermal cell proliferation was the factor responsible for driving asymmetric eye migration during flatfish metamorphosis (139). However, in these experimental conditions of sub-ocular colchicine-inhibited cell proliferation, the eye was still able to migrate $(>50 \%)$, albeit not as much as in normal developing larvae (139). This evidence suggested that, although cell proliferation is a factor involved in flatfish metamorphic eye migration, it is not the major mechanism that drives it. Later evidence in Senegalensis sole shows that asymmetric sub-ocular development and ossification of the pseudomesial bone (that develops only during flatfish metamorphosis and ventral to the migrating eye) is the major driving force of eye migration during metamorphosis (45). In methimazole treated sole larvae eye, migration was impaired, clearly showing that $\mathrm{TH}$ is the sufficient and necessary factor behind eye migration. Also, in these larvae, neither pseudomesial ossification nor sub-dermal cell proliferation was observed. This evidence shows that sub-ocular asymmetric ossification and subdermal proliferation are both $\mathrm{TH}$-driven events (45). Additional evidence using sub-ocular injection of apyrase [dermal bone differentiation inhibitor (140)] in pre-metamorphic sole larvae prevented pseudomesial ossification and most of the eye migration (only 5-15\% migration observed). These pieces of evidence show that pseudomesial ossification is the major force driving eye migration and asymmetric head development in sole metamorphosis (45). Given that pseudomesial bone asymmetric development at metamorphosis is a common event in all flatfish $(11,115,117,137,138)$, the findings in sole (45) argue that this is the mechanism by which asymmetric TH-driven head development occurs in all flatfish. Together, pseudomesial asymmetric ossification and cell proliferation are essential for proper eye migration in flatfish $(45,139)$. In this scenario, asymmetric flatfish eye migration itself is a passive event where the eye, the eye socket, ocular muscles, and the ocular nerve are all pushed to the opposite side of the head by asymmetric ossification of the pseudomesial bone together with sub-ocular cell proliferation $(45,139)$. Moreover, this event compresses the mesenchyme tissue in-between the eyes that also differentiates into bone, giving rise to the paramesial bone $(11,39,45,59,87$, $115,117,118,137,138)$. The tissue mechanics underlying this process are still unknown.

The pseudomesial bone arises from an asymmetric $\mathrm{TH}-$ responsive center, characterized by the co-expression of dio 2 and thrb, that increase in expression as metamorphosis progresses and terminate as soon as metamorphosis is completed (45). In the $\mathrm{TH}$-responsive center, $\mathrm{TH}$ regulates dio2 in a noncanonical fashion. Rather than increased concentrations of $\mathrm{TH}$ leading to decreased dio 2 expression, as is observed in symmetric developing structures in the sole head; in the asymmetric THresponsive center, dio2 expression is dependent and positively regulated by TH (45). Nonetheless, it is still not known which are the genetic factors behind this asymmetric sub-ocular expression pattern of dio2 during metamorphosis.

\section{GENETIC REGULATION OF FLATFISH METAMORPHIC EYE MIGRATION}

The genetic regulation of asymmetric head development in flatfish remains an elusive matter. It was suggested that flatfish metamorphic asymmetry is related to embryonic left-right (LR) asymmetric development by the Nodal-Lefty-Pitx2 pathway (141). In both P. olivaceus and Verasper variegatus, asymmetric habenular expression of pitx 2 was found during metamorphosis of these flatfish (141). Also, it has been argued that asymmetric pitx2 habelunar expression during metamorphosis led to the decreased size of the blind side habenula lobe that in turn generated a torsion force that would lead to both optic nerve and eye migration (141). However, no asymmetric nerve endings were shown to emerge after this asymmetric event. These observations raise questions about how pitx 2 asymmetric habenular expression can give rise to asymmetric pseudomesial 
ossification and cell proliferation that are the driving forces of flatfish eye migration $(45,139)$. Tentative efforts were also carried out to understand if blocking of pitx2 signaling, via ouabain exposure during embryogenesis, could lead to random migration of the eye. The reversal of normal eye migration occurred in a small proportion of individuals ( $\sim 6 \%)$, but the gross majority of these larvae metamorphosed normally (141).

Given that flatfish metamorphic eye migration is exclusively dependent on $\mathrm{TH}$, it is still not known if pitx2 expression in $P$. olivaceus and $V$. variegatus is dependent on TH. Moreover, Nodal-Lefty-Pitx2 embryonic signaling was independent of putative pitx2 asymmetric metamorphic development (141), further raising concerns about how this embryonic mechanism could lead to asymmetric metamorphic development. Notably, habenular asymmetry is not exclusive of flatfish and is also found in other bilateral teleosts (142), suggesting that the asymmetry in the habenula of $P$. olivaceus and $V$. variegatus might not be related to metamorphosis. Moreover, a detailed mapping of the nervous system during sole metamorphosis only found asymmetric differences in the olfactory epithelia, olfactory bulb and in the most anterior diencephalon that is encompassed by the eye field (45). Remarkably it was found that the olfactory epithelia and bulb only became asymmetric if there was eye migration but not in its absence. These pieces of evidence strongly suggest that the asymmetric metamorphic development of these brain structures was due to the force constraints brought about by pseudomesial asymmetric ossification. Consequently, eye migration is not directly caused by $\mathrm{TH}$-action on these structures. Curiously, in zebrafish embryogenesis, it was found that maternal $\mathrm{TH}$ are involved in establishing pitx2 expression in the developing pituitary but how or if this has any consequence in metamorphic pitx2 expression in zebrafish or any other teleost species remains unknown (143).

Up until now, the most detailed data available on asymmetric flatfish head metamorphic development only sheds light on how TH regulates asymmetric pseudomesial ossification that leads to eye migration (45). Several efforts have been made using next-generation transcriptomic approaches to solve this question (144-146). However, no definitive answer was obtained even using these high-throughput strategies. Alves et al. (147) sequenced the head transcriptome of metamorphosing halibut and found that the most significant differentially expressed transcripts (DET) were related to TH production. The wholebody transcriptome of metamorphosing Japanese flounder reports that the top DET were for genes related to bone development (145). Transcriptomics confirm that increased TH production is a crucial event in teleost metamorphosis and that bone development is a central aspect of teleost metamorphosis as already shown by several studies $(11,45,105-118)$. While this manuscript was in revision, a new study analyzing the transcriptome of dissected heads of metamorphosing sole larvae was published. In this study, it was also not possible to identify a single gene responsible for asymmetric head development during flatfish metamorphosis (148). Instead, it was reported that in the head of sole larvae undergoing metamorphosis, several different genetic cascades function in a time and stage-specific manner. The earliest changes are related to hormonal production, followed by protein and mRNA processing, cell cycle regulation, nuclear organization, and finally, DNA replication. Collectively, this evidence argues that metamorphosis in sole head occurs in a stepwise manner with earlier genetic cascades promoting the next stage of developmental changes. Also, this study shows that earlier occurring metamorphic events are at the organismal level while later events are at the cellular level, suggesting that metamorphosis progresses from changes in the organism to specific cellular responses (148). Nonetheless, neither study was able to identify a single gene or genetic mechanism behind asymmetric eye migration in flatfishes. These findings argue that asymmetric head development can be due to a combination of different flatfish specific genetic pathways that together give rise to asymmetric head development.

\section{TH AND SALMONID SMOLTIFICATION}

In most teleosts, a single surge in $\mathrm{TH}$ is found and related to the larval to juvenile transition, known as metamorphosis (discussed above). However, in salmonids, a second peak of T4 also occurs just before spontaneous smoltification $(24,149)$. TH treatment increases survival of salmonids after SW transfer (150), further arguing that $\mathrm{TH}$ are involved in salmonid smoltification. The evidence seemed to suggest that $\mathrm{T} 4$ levels are directly related to the adaptability of salmon to seawater (SW) and parr fish that are not able to adapt to SW present hypothyroidism (150). Also, $\mathrm{TH}$ are involved in the acquisition of the specific morphological changes that come with smolting like silvering and behavior responses like downstream migration (151).

Little is known about the tissue-specific developmental events driven by TH during the parr to smolt transition in salmonids. An early study reported that brain and hepatic T4 levels increase before plasma levels, whereas muscle T4 content decreased as soon as plasma T4 levels increased (152). Nonetheless, the biological consequences of different organ $\mathrm{T} 4$ content and timing are still unknown. A more recent study provided evidence showing THs are involved in both the light response and gill seawater adaptation observed in salmons undergoing smoltification (153). In this study, Lorgen et al. (153) show that different dio2 paralogs are involved in different tissue responsivity to $\mathrm{TH}$, but the exact consequences of this differential $\mathrm{TH}$ cell signaling remain elusive.

Nonetheless, this evidence suggests that $\mathrm{TH}$ might have a role in integrating environmental cues that allow for the specific adaptions needed for seawater transition and that these changes are brought about by complex peripheral regulation of TH metabolism. Notably, T4 levels increase in wild smolts, whereas in hatchery smolts T4 levels remain stable (154), suggesting that the role of $\mathrm{TH}$ in salmonid smoltification is complex and likely linked to environmental cues. Albeit this evidence, and in contrast to metamorphosis that is considered a larval to juvenile transition, $\mathrm{TH}$ are not the necessary and sufficient factors regulating smolting. In both anuran and teleost metamorphosis, $\mathrm{T} 4$ and $\mathrm{T} 3$ increase to give rise to this developmental transition. However, instead in salmon smoltification, T4 but not T3 levels increase $(24,149,152$, 
154). Taken together the evidence seems to suggest that $\mathrm{TH}$ participate, together with other endocrine factors [revised in (155)], in the transition from parr to smolt but they are not the essential factor triggering smoltification. As a whole, salmonid smoltification is likely to be a developmental transition specific of this class of teleost that is mediated by several endocrine factors including $\mathrm{TH}$.

\section{FUTURE PERSPECTIVES}

The evidence so far obtained on teleost metamorphosis highlight the role of TH as an integrative factor able to give rise to a series of synchronized developmental changes across the entire organism. These prepare the organism for the physiological and ecological challenges of juvenile animals. Despite recent advances, teleost metamorphosis is still an understudied developmental event. Important questions at the core of this developmental process are still not answered. These include: (1) how central regulation of the onset of metamorphosis is achieved and; in the case of flatfish metamorphosis, (2) which are the TH-dependent genetic and cellular mechanisms behind asymmetric head development. Other aspects like the role of TH metabolites other than T4 and T3 during metamorphosis are mostly unstudied.

Also, a recent study implicated genetic divergence in $t s h$ paralogs locus in mediating and modulating $\mathrm{TH}$ signaling and physiological adaptation in three spine-sticklebacks marine and freshwater ecotypes (156). Although no exact

\section{REFERENCES}

1. Volff JN. Genome evolution and biodiversity in teleost fish. Heredity. (2005) 94:280-94. doi: 10.1038/sj.hdy.6800635

2. Gorbman A, Bern HA. A Textbook of Comparative Endocrinology. New York,NY: John Wiley \& Sons (1962). doi: 10.1097/00000441-196208000-00033

3. Inui Y, Miwa S. Thyroid hormone induces metamorphosis of flounder larvae. Gen Comp Endocr. (1985) 60:450-4. doi: 10.1016/0016-6480(85)90080-2

4. Inui Y, Tagawa M, Miwa S, Hirano T. Effects of bovine TSH on the tissue thyroxine level and metamorphosis in prometamorphic flounder larvae. Gen Comp Endocr. (1989) 74:406-10. doi: 10.1016/S0016-6480(89)80038-3

5. Inui $\mathrm{Y}$, Yamano $\mathrm{K}$, Miwa S. The role of thyroid hormone in tissue development in metamorphosing flounder. Aquaculture. (1995) 135:8798. doi: 10.1016/0044-8486(95)01017-3

6. Miwa S, Tagawa $M$, Inui $Y$, Hirano $T$. Thyroxine surge in metamorphosing flounder larvae. Gen Comp Endocr. (1988) 70:158-63. doi: 10.1016/0016-6480(88)90105-0

7. Tagawa M, Miwa S, Inui Y, Dejesus EG, Hirano T. Changes in thyroidhormone concentrations during early development and metamorphosis of the flounder, paralichthys- olivaceus. Zool Sci. (1990) 7:93-6.

8. Yamano K, Tagawa M, Dejesus EG, Hirano T, Miwa S, Inui Y. Changes in whole body concentrations of thyroid hormones and cortisol in metamorphosing conger eel. J Comp Physiol B Biochem Syst Environ Physiol. (1991) 161:371-5. doi: 10.1007/BF00260795

9. Huang LY, Miwa S, Bengtson DA, Specker JL. Effect of triiodothyronine on stomach formation and pigmentation in larval striped bass (Morone saxatilis). J Exp Zool. (1998) 280: 231-7. doi: 10.1002/(SICI)1097010X(19980215)280:3<;231::AID-JEZ4>3.0.CO;2-O

10. Isorna E, Obregon M-J, Calvo RM, Vázquez R, Pendón C, Falcón J, et al. Iodothyronine deiodinases and thyroid hormone receptors regulation during molecular mechanism or developmental/metamorphose-related implications of divergent $\mathrm{TH}$ signaling were found between the two ecotypes, these evidences also highlight the potential capacity of TH for promoting speciation in teleosts (156).

The advent and fast pace of development of new technologies will allow for better discrimination of the genetic events during teleost metamorphosis and TH signaling in general. Also, more powerful imaging technologies for large specimens open the door for discoveries and better insight into morphological development observed during teleost metamorphosis.

\section{AUTHOR CONTRIBUTIONS}

The author confirms being the sole contributor of this work and has approved it for publication.

\section{FUNDING}

Fundação para a Ciência e Tecnologia, Portugal.

\section{ACKNOWLEDGMENTS}

MAC is a recipient of an FCT IF2014 Starting Grant (IF/01274/2014). Portuguese national funds from FCTFoundation for Science and Technology through project UID/Multi/04326/2016 (CCMAR). Dr. Juan Fuentes for comments on the manuscript. flatfish (Solea senegalensis) metamorphosis. J Exp Zool B Mol Dev Evol. (2009) 312B:231-46. doi: 10.1002/jez.b.21285

11. Sæle $\varnothing$, Solbakken JS, Watanabe K, Hamre K, Power D, Pittman K. Staging of Atlantic halibut (Hippoglossus hippoglossus L.) from first feeding through metamorphosis, including cranial ossification independent of eye migration. Aquaculture. (2004) 239:445-65. doi: 10.1016/j.aquaculture.2004.05.025

12. Miwa S, Inui Y. Effects of various doses of thyroxine and triiodothyronine on the metamorphosis of flounder (Paralichthys olivaceus). Gen Comp Endocr. (1987) 67:356-63. doi: 10.1016/0016-6480(87)90190-0

13. Marchand O, Duffraisse M, Triqueneaux G, Safi R, Laudet V. Molecular cloning and developmental expression patterns of thyroid hormone receptors and $\mathrm{T} 3$ target genes in the turbot (Scophtalmus maximus) during post-embryonic development. Gen Comp Endocrinol. (2004) 135:34557. doi: 10.1016/j.ygcen.2003.10.012

14. P.Klaren HM, Wunderink YS, Yúfera M, Mancera JM, Flik G. The thyroid gland and thyroid hormones in Senegalese sole (Solea senegalensis) during early development and metamorphosis. Gen Comp Endocr. (2008) 155:68694. doi: 10.1016/j.ygcen.2007.09.014

15. Jegstrup IM, Rosenkilde P. Regulation of post-larval development in the European eel: thyroid hormone level, progress of pigmentation and changes in behaviour. J Fish Biol. (2003) 63:168-75. doi: 10.1046/j.1095-8649.2003.00138.x

16. Campinho MA, Galay-Burgos M, Sweeney GE, Power DM. Coordination of deiodinase and thyroid hormone receptor expression during the larval to juvenile transition in sea bream (Sparus aurata, Linnaeus). Gen Comp Endocr. (2010) 165:181-94. doi: 10.1016/j.ygcen.2009.0 6.020

17. de Jesus EG, Hirano T, Inui Y. Changes in cortisol and thyroid hormone concentrations during early development and metamorphosis in the Japanese flounder, Paralichthys olivaceus. Gen Comp Endocr. (1991) 82:36976. doi: 10.1016/0016-6480(91)90312-T 
18. de Jesus EG, Toledo JD, Simpas MS. Thyroid hormones promote early metamorphosis in grouper (Epinephelus coioides) larvae. Gen Comp Endocr. (1998) 112:10-6. doi: 10.1006/gcen.1998.7103

19. Brown DD. The role of thyroid hormone in zebrafish and axolotl development. Proc Natl Acad Sci USA. (1997) 94:130116. doi: 10.1073/pnas.94.24.13011

20. Chang J, Wang M, Gui W, Zhao Y, Yu L, Zhu G. Changes in thyroid hormone levels during zebrafish development. Zool Sci. (2012) 29:1814. doi: 10.2108/zsj.29.181

21. J.-Shiao C, Hwang P-P. Thyroid hormones are necessary for the metamorphosis of tarpon Megalops cyprinoides leptocephali. J Exp Mar Biol Ecol. (2006) 331:121-32. doi: 10.1016/j.jembe.2005.10.014

22. Taillebois L, Keith P, Valade P, Torres P, Baloche S, Dufour S, et al. Involvement of thyroid hormones in the control of larval metamorphosis in Sicyopterus lagocephalus (Teleostei: Gobioidei) at the time of river recruitment. Gen Comp Endocr. (2011) 173:2818. doi: 10.1016/j.ygcen.2011.06.008

23. Boeuf G, Gaignon J-L. Effects of rearing conditions on growth and thyroid hormones during smolting of Atlantic salmon, Salmo salar L. Aquaculture. (1989) 82:29-38. doi: 10.1016/0044-8486(89)90 393-1

24. Specker JL. Preadaptive role of thyroid hormones in larval and juvenile salmon: growth, the gut and evolutionary considerations. Am Zool. (1988) 28:337-49. doi: 10.1093/icb/28.2.337

25. Fliers E, Unmehopa UA, Alkemade A. Functional neuroanatomy of thyroid hormone feedback in the human hypothalamus and pituitary gland. Mol Cell Endocrinol. (2006) 251:1-8. doi: 10.1016/j.mce.2006.03.042

26. De Groef B, Van der Geyten S, Darras VM, Kühn ER. Role of corticotropin-releasing hormone as a thyrotropin-releasing factor in non-mammalian vertebrates. Gen Comp Endocr. (2006) 146:62-8. doi: 10.1016/j.ygcen.2005.10.014

27. Denver RJ. Chapter seven - neuroendocrinology of amphibian metamorphosis. In: Yun-Bo S, editor. Current Topics in Developmental Biology. San Diego, CA: Academic Press (2013). p. 195-227. doi: 10.1016/B978-0-12-385979-2.00007-1

28. Manchado $M$, Infante $C$, Asensio $E$, Planas JV, Cañavate JP. Thyroid hormones down-regulate thyrotropin [beta] subunit and thyroglobulin during metamorphosis in the flatfish Senegalese sole (Solea senegalensis Kaup). Gen Comp Endocr. (2008) 155:447-55. doi: 10.1016/j.ygcen.2007.07.011

29. Iziga $R$, Ponce $M$, Infante $C$, Rebordinos $L$, Cañavate JP, Manchado $M$. Molecular characterization and gene expression of thyrotropin-releasing hormone in Senegalese sole (Solea senegalensis). Comp Biochem Physiol B Biochem Mol Biol. (2010) 157:167-74. doi: 10.1016/j.cbpb.2010.05.013

30. Han Y, Liao I, Tzeng W, Yu J. Cloning of the cDNA for thyroid stimulating hormone beta subunit and changes in activity of the pituitary-thyroid axis during silvering of the Japanese eel, Anguilla japonica. J Mol Endocrinol. (2004) 32:179-94. doi: 10.1677/jme.0.0320179

31. Chatterjee A, Hsieh YL, Yu JY. Molecular cloning of cDNA encoding thyroid stimulating hormone beta subunit of bighead carp Aristichthys nobilis and regulation of its gene expression. Mol Cell Endocrinol. (2001) 174:1-9. doi: 10.1016/S0303-7207(01)00392-6

32. Larsen DA, Swanson P, Dickey JT, Rivier J, Dickhoff WW. In vitro thyrotropin-releasing activity of corticotropin-releasing hormone-family peptides in coho salmon, Oncorhynchus kisutch. Gen Comp Endocrinol. (1998) 109:276-85. doi: 10.1006/gcen.1997.7031

33. Matz SP, Hofeldt GT. Immunohistochemical localization of corticotropinreleasing factor in the brain and corticotropin-releasing factor and thyrotropin-stimulating hormone in the pituitary of chinook salmon (Oncorhynchus tshawytscha). Gen Comp Endocrinol. (1999) 114:15160. doi: 10.1006/gcen.1999.7253

34. Chowdhury I, Chien JT, Chatterjee A, Yu JY. In vitro effects of mammalian leptin, neuropeptide-Y, beta-endorphin and galanin on transcript levels of thyrotropin beta and common alpha subunit mRNAs in the pituitary of bighead carp (Aristichthys nobilis). Comp Biochem Physiol B Biochem Mol Biol. (2004) 139:87-98. doi: 10.1016/j.cbpc.2004.06.007

35. Sukumar P, Munro AD, Mok EY, Subburaju S, Lam TJ. Hypothalamic regulation of the pituitary-thyroid axis in the tilapia Oreochromis mossambicus. Gen Comp Endocrinol. (1997) 106:73-84. doi: 10.1006/gcen.1996.6852

36. MacKenzie DS, Sokolowska M, Peter RE, Breton B. Increased gonadotropin levels in goldfish do not result in alterations in circulating thyroid hormone levels. Gen Comp Endocrinol. (1987) 67:202-13. doi: 10.1016/0016-6480(87)90149-3

37. Peter RE. Comparison of the activity of the pronephric thyroid and the pharyngeal thyroid of the goldfish, Carassius auratus. Gen Comp Endocrinol. (1970) 15:88-94. doi: 10.1016/0016-6480(70)90100-0

38. Power DM, Einarsdóttir IE, Pittman K, Sweeney GE, Hildahl J, Campinho MA, et al. The molecular and endocrine basis of flatfish metamorphosis. Rev Fish Sci. (2008) 16:95-111. doi: 10.1080/10641260802325377

39. Campinho MA, Galay-Burgos M, Silva N, Costa RA, Alves RN, Sweeney GE. Molecular and cellular changes in skin and muscle during metamorphosis of Atlantic halibut (Hippoglossus hippoglossus) are accompanied by changes in deiodinases expression. Cell Tissue Res. (2012) 350:33346. doi: 10.1007/s00441-012-1473-x

40. Campinho MA, Morgado I, Pinto PIS, Silva N, Power DM. The goitrogenic efficiency of thioamides in a marine teleost, sea bream (Sparus auratus). Gen Comp Endocr. (2012) 179:369-75. doi: 10.1016/j.ygcen.2012.09.022

41. Campinho MA, Silva N, Roman-Padilla J, Ponce M, Manchado M, Power DM. Flatfish metamorphosis: a hypothalamic independent process? Mol Cell Endocrinol. (2015) 404:16-25. doi: 10.1016/j.mce.2014.12.025

42. Ponce $\mathrm{M}$, Infante $\mathrm{C}$, Manchado $\mathrm{M}$. Molecular characterization and gene expression of thyrotropin receptor (TSHR) and a truncated TSHR-like in Senegalese sole. Gen Comp Endocr. (2010) 168:4319. doi: 10.1016/j.ygcen.2010.05.012

43. Llewellyn L, Nowell MA, Ramsurn VP, Wigham T, Sweeney GE, Kristjánsson B, et al. Molecular cloning and developmental expression of the halibut thyroid hormone receptor-a. J Fish Biol. (1999) 55:14855. doi: 10.1111/j.1095-8649.1999.tb01052.x

44. Galay-Burgos M, Power DM, Llewellyn L, Sweeney GE. Thyroid hormone receptor expression during metamorphosis of Atlantic halibut (Hippoglossus hippoglossus). Mol Cell Endocrinol. (2008) 281:56-63. doi: 10.1016/j.mce.2007.10.009

45. Campinho MA, Silva N, Martins GG, Anjos L, Florindo C, Roman-Padilla J, et al. A thyroid hormone regulated asymmetric responsive centre is correlated with eye migration during flatfish metamorphosis. Sci Rep. (2018) 8:12267. doi: 10.1038/s41598-018-29957-8

46. Balon EK. Alternative ways to become a juvenile or a definitive phenotype (and on some persisting linguistic offenses). Environ Biol Fishes. (1999) 56:17-38. doi: 10.1007/978-94-017-3678-7_2

47. Osse JW. Form changes in fish larvae in relation to changing demands of function. Netherlands $J$ Zool. (1990) 40:36285. doi: 10.1163/156854289X00354

48. Müller UK, van den Boogaart JGM, van Leeuwen JL. Flow patterns of larval fish: undulatory swimming in the intermediate flow regime. J Exp Biol. (2008) 211:196-205. doi: 10.1242/jeb.005629

49. Song J, Zhong Y, Luo H, Ding Y, Du R. Hydrodynamics of larval fish quick turning: a computational study. Proc Inst Mech Eng Part C J Mech Eng Sci. (2018) 232: 2515-2523. doi: 10.1177/0954406217743271

50. Voesenek CJ, Muijres FT, van Leeuwen JL. Biomechanics of swimming in developing larval fish. J Exp Biol. (2018) 221:jeb149583. doi: 10.1242/jeb.149583

51. J.Koumans TM, Akster HA. Myogenic cells in development and growth of fish. Comp Biochem Physiol Part A Physiol. (1995) 110:3-20. doi: 10.1016/0300-9629(94)00150-R

52. Patruno M, Radaelli G, Mascarello F, Candia-Carnevali M. Muscle growth in response to changing demands of functions in the teleost Sparus aurata (L.) during development from hatching to juvenile. Anat Embryol. (1998) 198:487-504. doi: 10.1007/s004290050199

53. Stoiber W, Haslett J, Sanger A. Myogenic patterns in teleosts: what does the present evidence really suggest? J Fish Biol. (1999) 55:8499. doi: 10.1111/j.1095-8649.1999.tb01047.x

54. Mascarello F, Romanello MG, Scapolo PA. Histochemical and immunohistochemical profile of pink muscle fibers in some teleosts. Histochemistry. (1986) 84:251-5. doi: 10.1007/BF0049 5791 
55. Mascarello F, Rowlerson A, Radaelli G, Scapolo P, Veggetti A. Differentiation and growth of muscle in the fish Sparus aurata (L): I. Myosin expression and organization of fibre types in lateral muscle from hatching to adult. J Muscle Res Cell Motil. (1995) 16:213-22. doi: 10.1007/BF00121130

56. Mascarello F, Rowlerson A, Scapolo PA, Veggetti A. Differentiation of lateral muscle-fibers in Dicentrarchus-Labrax (L). J Muscle Res Cell Motil. (1989) 10:174-5.

57. Mascarello F, Rowlerson A, Veggetti A. Hyperplasia of lateral muscle during normal growth of the sea-bream, Sparus-Aurata. J Muscle Res Cell Motil. (1994) 15:189.

58. Chauvigne F, Ralliere C, Cauty C, Rescan P. In situ hybridisation of a large repertoire of muscle-specific transcripts in fish larvae: the new superficial slow-twitch fibres exhibit characteristics of fast-twitch differentiation. J Exp Biol. (2006) 209:372-9. doi: 10.1242/jeb.02006

59. Campinho MA, Silva N, Nowell M, Llewellyn L, Sweeney G, Power DM. Troponin $\mathrm{T}$ isoform expression is modulated during Atlantic Halibut metamorphosis. BMC Dev Biol. (2007) 7:71. doi: 10.1186/1471-213X-7-71

60. Campinho MA, Sweeney GE, Power DM. Regulation of troponin $\mathrm{T}$ expression by thyroid hormones during muscle development in sea bream (Sparus auratus, Linnaeus). J Exp Biol. (2006) 209:475167. doi: $10.1242 /$ jeb. 02555

61. Hsiao C, Tsai W, Horng L, Tsai H. Molecular structure and developmental expression of the three muscle-type troponin T genes in zebrafish. Dev Dyn. (2003) 227:266-79. doi: 10.1002/dvdy.10305

62. Xu J, Ke Z, Xia J, He F, Bao B. Change of body height is regulated by thyroid hormone during metamorphosis in flatfishes and zebrafish. Gen Comp Endocr. (2016) 236:9-16. doi: 10.1016/j.ygcen.2016.06.028

63. Moutou KA, Canario AV, Mamuris Z, Power DM. Molecular cloning and sequence of Sparus aurata skeletal myosin light chains expressed in white muscle: developmental expression and thyroid regulation. J Exp Biol. (2001) 204:3009-18.

64. Moutou KA, Socorro S, Power DM, Mamuris Z, Canario AV. Molecular cloning and sequence of gilthead sea bream (Sparus aurata) alpha-skeletal actin: tissue and developmental expression. Comp Biochem Physiol. B Biochem Mol Biol. (2001) 130:13-21. doi: 10.1016/S1096-4959(01)00381-5

65. Johnston IA. Development and plasticity of fish muscle with growth. Basic Appl Myol. (1994) 4:353-68.

66. Johnston IA, Manthri S, Alderson R, Smart A, Campbell P, Nickell D, et al. Freshwater environment affects growth rate and muscle fibre recruitment in seawater stages of Atlantic salmon (Salmo salar L.). J Exp Biol. (2003) 206(Pt 8):1337-51. doi: 10.1242/jeb.00262

67. Garcia de la Serrana D, Estevez A, Andree K, Johnston IA. Fast skeletal muscle transcriptome of the gilthead sea bream (Sparus aurata) determined by next generation sequencing. BMC Genomics. (2012) 13:181. doi: 10.1186/1471-2164-13-181

68. Campinho MA, Power DM, Sweeney GE. Identification and analysis of teleost slow muscle troponin $\mathrm{T}(\mathrm{sTnT})$ and intronless TnT genes. Gene. (2005) 361:67-79. doi: 10.1016/j.gene.2005.07.003

69. Focant B, Vanderwalle P, Huriaux F. Expression of myofibrillar proteins and parvalbumin isoforms during the development of a flatfish, the common sole Solea solea: comparison with the turbot Scophthalmus maximus. Comp Biochem Phys B. (2003) 135:493-502. doi: 10.1016/S1096-4959(03)00116-7

70. Yamano K, Miwa S, Obinata T, Inui Y. Thyroid hormone regulates developmental changes in muscle during flounder metamorphosis. Gen Comp Endocr. (1991) 81:464-72. doi: 10.1016/0016-6480(91)90174-5

71. Vadaszova A, Zacharova G, Machacova K, Jirmanova I, Soukup T. Influence of thyroid status on the differentiation of slow and fast muscle phenotypes. Physiol Res. (2004) 53(Suppl. 1):S57-61.

72. Everts M. Effects of thyroid hormones on contractility and cation transport in skeletal muscle. Acta Physiol Scand. (1996) 156:32533. doi: 10.1046/j.1365-201X.1996.203000.x

73. Goldspink G. Postembryonic growth and differentiation of striated muscle. In: Bourne GH, editor. The Structure and Function of Muscle. New York, NY: Academic Press (1972). p. 179-236. doi: 10.1016/B978-0-12-119101-6.50012-3

74. Rowlerson A, Mascarello F, Radaelli G, Veggetti A. Differentiation and growth of muscle in the fish Sparus aurata (L): II Hyperplastic and hypertrophic growth of lateral muscle from hatching to adult.
J Muscle Res Cell Motil. (1995) 16:223-36. doi: 10.1007/BF001 21131

75. Rowlerson A, Scapolo PA, Mascarello F, Carpene E, Veggetti A. Comparative-study of myosins present in the lateral muscle of some fish - species variations in myosin isoforms and their distribution in red, pink and white muscle. J Muscle Res Cell Motil. (1985) 6:60140. doi: 10.1007/BF00711917

76. Wilkes D, Xie SQ, Stickland NC, Alami-Durante H, Kentouri M, Sterioti A, et al. Temperature and myogenic factor transcript levels during early development determines muscle growth potential in rainbow trout (Oncorhynchus mykiss) and sea bass (Dicentrarchus labrax). J Exp Biol. (2001) 204(Pt 16):2763-71.

77. Salvatore D, Simonides WS, Dentice M, Zavacki AM, Larsen PR. Thyroid hormones and skeletal muscle-new insights and potential implications. Nature reviews. Endocrinology. (2014) 10:206-14. doi: 10.1038/nrendo.2013.238

78. Auman HJ, Yelon D. Vertebrate organogenesis: getting the heart into shape. Curr Biol. (2004) 14:R152-3. doi: 10.1016/j.cub.2004.01.044

79. Yelon D. Cardiac patterning and morphogenesis in zebrafish. Dev Dyn. (2001) 222:552-63. doi: 10.1002/dvdy.1243

80. Mommsen T. Paradigms of growth in fishes. Comp Biochem Physiol B Biochem Mol Biol. (2001) 129:201-19. doi: 10.1016/S1096-4959(01)00312-8

81. Eales JG. Kinetics of $\mathrm{T} 4$ and $\mathrm{T} 3$ binding to plasma sites in salmonid teleost fish. Gen Comp Endocrinol. (1987) 65:28899. doi: 10.1016/0016-6480(87)90176-6

82. Iuchi I. Chemical and physiological properties of the larval and the adult hemoglobins in rainbow trout, Salmo gairdnerii irideus. Comp Biochem Physiol B. (1973) 44:1087-101. doi: 10.1016/0305-0491(73)90262-9

83. Iuchi I, Suzuki R, Yamagami K. Ontogenetic expression of larval and adult hemoglobin phenotypes in the intergeneric salmonid hybrids. J Exp Zool. (1975) 192:57-64. doi: 10.1002/jez.1401920107

84. Miwa S, Inui Y. Thyroid hormone stimulates the shift of erythrocyte populations during metamorphosis of the flounder. J Exp Zool. (1991) 259:222-8. doi: 10.1002/jez.1402590211

85. Kobel HR, Wolff J. Two transitions of haemoglobin expression in Xenopus: from embryonic to larval and from larval to adult. Differentiation. (1983) 24:24-6. doi: 10.1111/j.1432-0436.1983.tb01297.x

86. Masami W, Masahiro Y. Erythropoiesis and conversion of RBCs and hemoglobins from larval to adult type during amphibian development. BIOONE. (2001) 18:891-904. doi: 10.2108/zsj.18.891

87. Campinho MA, Silva N, Sweeney GE, Power DM. Molecular, cellular and histological changes in skin from a larval to an adult phenotype during bony fish metamorphosis. Cell Tissue Res. (2007) 327:26784. doi: 10.1007/s00441-006-0262-9

88. Le Guellec D, Morvan-Dubois G, Sire JY. Skin development in bony fish with particular emphasis on collagen deposition in the dermis of the zebrafish (Danio rerio). Int J Dev Biol. (2004) 48:217-31. doi: 10.1387/ijdb.15272388

89. Roberts RJ, Bell M, Young H. Studies on the skin of plaice (pleuronectes platessa L.) II. The development of larval plaice skin. J Fish Biol. (1973) 5:103-8. doi: 10.1111/j.1095-8649.1973.tb04435.x

90. Ottensen $\mathrm{OH}$, Olafsen JA. Ontogenetic development and composition of the mucous cells and the occurrence of saccular cells in the epidermis of atlantic halibut. J Fish Biol. (1997) 50:620-33. doi: 10.1006/jfbi.199 6.0329

91. Murray HM, Hew CL, Fletcher GL. Spatial expression patterns of skin-type antifreeze protein in winter flounder (Pseudopleuronectes americanus) epidermis following metamorphosis. J Morphol. (2003) 257:78-86. doi: 10.1002/jmor.10109

92. W.-Chang J, Hwang P-P. Development of zebrafish epidermis. Birth Defects Res C Embryo Today Rev. (2011) 93:205-14. doi: 10.1002/bdrc.20215

93. Parichy DM, Elizondo MR, Mills MG, Gordon TN, Engeszer RE. Normal table of postembryonic zebrafish development: staging by externally visible anatomy of the living fish. Dev Dyn. (2009) 238:29753015. doi: 10.1002/dvdy.22113

94. Budi EH, Patterson LB, Parichy DM. Embryonic requirements for ErbB signaling in neural crest development and adult pigment pattern formation. Development. (2008) 135:2603-14. doi: 10.1242/dev.01 9299 
95. Watanabe K, Washio Y, Fujinami Y, Aritaki M, Uji S, Suzuki T. Adult-type pigment cells, which color the ocular sides of flounders at metamorphosis, localize as precursor cells at the proximal parts of the dorsal and anal fins in early larvae. Dev Growth Diff. (2008) 50:73141. doi: 10.1111/j.1440-169X.2008.01071.x

96. Yamada T, Okauchi M, Araki K. Origin of adult-type pigment cells forming the asymmetric pigment pattern, in Japanese flounder (Paralichthys olivaceus). Dev Dyn. (2010) 239:3147-62. doi: 10.1002/dvdy.22440

97. Guillot R, Muriach B, Rocha A, Rotllant J, Kelsh RN, Cerdá-Reverter JM. Thyroid hormones regulate zebrafish melanogenesis in a gender-specific manner. PLoS ONE. (2016) 11:e0166152. doi: 10.1371/journal.pone.0166152

98. Sire M-Y, Aakimenko M-A. Scale development in fish: a review, with description of sonic hedgehog (shh) expression in the zebrafish (Danio rerio). Int J Dev Biol. (2004) 48:233-47. doi: 10.1387/ijdb.15272389

99. Alibardi L. Immunocytochemical localisation of keratins, associated proteins and uptake of histidine in the epidermis of fish and amphibians. Acta Histochem. (2002) 104:297-310. doi: 10.1078/0065-1281-00651

100. Infante C, Manchado M, Asensio E, Canavate J. Molecular characterization, gene expression and dependence on thyroid hormones of two type I keratin genes (sseKer1 and sseKer2) in the flatfish Senegalese sole (Solea senegalensis Kaup). BMC Dev Biol. (2007) 7:118. doi: 10.1186/1471-213X-7-118

101. Schreiber A, Brown DD. Tadpole skin dies autonomously in response to thyroid hormone at metamorphosis. Proc Natl Acad Sci USA. (2003) 100:1769-74. doi: 10.1073/pnas.252774999

102. Suzuki K-I, Utoh R, Kotani K, Obara M, Yoshizato K. Lineage of anuran epidermal basal cells and their differentiation potential in relation to metamorphic skin remodeling. Dev Growth Differ. (2002) 44:22538. doi: 10.1046/j.1440-169X.2002.00637.x

103. Ishida Y, Suzuki K, Utoh R, Obara M, Yoshizato K. Molecular identification of the skin transformation center of anuran larval skin using genes of Rana adult keratin (RAK) and SPARC as probes. Dev Growth Diff. (2003) 45:515-26. doi: 10.1111/j.1440-169X.2003.00719.x

104. Bassett JHD, Williams GR. Role of thyroid hormones in skeletal development and bone maintenance. Endoc Rev. (2016) 37:135-87. doi: 10.1210/er.2015-1106

105. Wagemans F, Vandewalle P. Development of the cartilaginous skull in solea solea: trends in pleuronectiforms. Ann Sci Nat. (1999) 20:3952. doi: 10.1016/S0003-4339(99)80007-0

106. Wagemans F, Focant B, Vandewalle P. Early development of the cephalic skeleton in the turbot. J Fish Biol. (1998) 52:166-204. doi: 10.1111/j.1095-8649.1998.tb01561.x

107. Pavlov DA, Moksness E. Development of the axial skeleton in wolffish, Anarhichas lupus (Pisces, Anarhichadidae), at different temperatures. Environ Biol Fishes. (1997) 49:401-16.

108. Li N, Felber K, Elks P, Croucher P, Roehl HH. Tracking gene expression during zebrafish osteoblast differentiation. Dev Dyn. (2009) 238:45966. doi: 10.1002/dvdy.21838

109. Lewis LM, Lall SP. Development of the axial skeleton and skeletal abnormalities of Atlantic halibut (Hippoglossus hippoglossus) from first feeding through metamorphosis. Aquaculture. (2006) 257:124-35. doi: 10.1016/j.aquaculture.2006.02.067

110. Gavaia PJ, Simes DC, Ortiz-Delgado JB, Viegas CS, Pinto JP, Kelsh RN, et al. Osteocalcin and matrix Gla protein in zebrafish (Danio rerio) and Senegal sole (Solea senegalensis): Comparative gene and protein expression during larval development through adulthood. Gene Expr Patterns. (2006) 6:637-52. doi: 10.1016/j.modgep.2005.11.010

111. Fujita K, Oozeki Y. Development of the caudal skeleton in the saury, Cololabis saira. Jpn J Ichthyol. (1994) 41:334-7.

112. Fujita K. Caudal skeleton ontogeny in the andrianichthyid fish, Oryzias latipes. Jpn J Ichthyol. (1992) 39:107-9.

113. Fernández I, Granadeiro L, Darias MJ, Gavaia PJ, Andree KB, Gisbert E. Solea senegalensis skeletal ossification and gene expression patterns during metamorphosis: new clues on the onset of skeletal deformities during larval to juvenile transition. Aquaculture. (2018) 496:153-65. doi: 10.1016/j.aquaculture.2018.07.022

114. Faustino M, Power DM. Osteologic development of the viscerocranial skeleton in sea bream: alternative ossification strategies in teleost fish. J Fish Biol. (2001) 58:537-72. doi: 10.1111/j.1095-8649.2001.tb02272.x
115. Sæle $\varnothing$, Silva N, Pittman K. Post embryonic remodelling of neurocranial elements, a comparative study of normal versus abnormal eye migration in the flatfish Atlantic halibut. J Anat. (2006) 209:31-41. doi: 10.1111/j.1469-7580.2006.00577.x

116. Campinho MA, Moutou KA, Power DM. Temperature sensitivity of skeletal ontogeny in Oreochromis mossambicus. J Fish Biol. (2004) 65:100325. doi: 10.1111/j.0022-1112.2004.00505.X

117. Okada N, Takagi Y, Seikai T, Tanaka M, Tagawa M. Asymmetrical development of bones and soft tissues during eye migration of metamorphosing Japanese flounder, Paralichthys olivaceus. Cell Tissue Res. (2001) 304:59-66. doi: 10.1007/s004410100353

118. Okada N, Takagi Y, Tanaka M, Tagawa M. Fine structure of soft and hard tissues involved in eye migration in metamorphosing Japanese flounder (Paralichthys olivaceus). Anat Rec A Discov Mol Cell Evol Biol. (2003) 273:663-8. doi: 10.1002/ar.a.10074

119. Ishizuya-Oka A. How thyroid hormone regulates transformation of larval epithelial cells into adult stem cells in the amphibian intestine. Mol Cell Endocrinol. (2017) 459:98-103. doi: 10.1016/j.mce.2017.02.026

120. Sirakov M, Skah S, Lone IN, Nadjar J, Angelov D, Plateroti M. Multilevel interactions between the nuclear receptor TRCE \pm 1 and the $\mathrm{WNT}$ effectors $\mathbb{E} \leq$-Catenin/Tcf4 in the intestinal epithelium. PLoS ONE. (2012) 7:e34162. doi: 10.1371/journal.pone.0034162

121. Sirakov $M$, Plateroti $M$. The thyroid hormones and their nuclear receptors in the gut: from developmental biology to cancer. Biochim Biophys Acta. (2011) 1812:938-46. doi: 10.1016/j.bbadis.2010.12.020

122. Sirakov M, Boussouar A, Kress E, Frau C, Lone IN, Nadjar J, et al. The thyroid hormone nuclear receptor TR $\alpha 1$ controls the Notch signaling pathway and cell fate in murine intestine. Development. (2015) 142:276474. doi: 10.1242/dev.121962

123. Liu YW, Chan WK. Thyroid hormones are important for embryonic to larval transitory phase in zebrafish. Differentiation. (2002) 70:3645. doi: 10.1046/j.1432-0436.2002.700104.x

124. Garcia Hernandez MP, Lozano MT, Elbal MT, Agulleiro B. Development of the digestive tract of sea bass (Dicentrarchus labrax L). Light and electron microscopic studies. Anat Embryol. (2001) 204:39-57. doi: 10.1007/s004290100173

125. Armesto P, Infante C, Cousin X, Ponce M, Manchado M. Molecular and functional characterization of seven $\mathrm{Na}+/ \mathrm{K}+$-ATPase beta subunit paralogs in Senegalese sole (Solea senegalensis Kaup, 1858). Comp Biochem Physiol B Biochem Mol Biol. (2015) 182:14-26. doi: 10.1016/j.cbpb.2014.11.011

126. Gomes A, Kamisaka Y, Harboe T, Power D, Ronnestad I. Functional modifications associated with gastrointestinal tract organogenesis during metamorphosis in Atlantic halibut (Hippoglossus hippoglossus). BMC Dev Biol. (2014) 14:11. doi: 10.1186/1471-213X-14-11

127. Gomes AS, Alves RN, Rønnestad I, Power DM. Orchestrating change: the thyroid hormones and GI-tract development in flatfish metamorphosis. Gen Comp Endocrinol. (2015) 220:2-12. doi: 10.1016/j.ygcen.2014.06.012

128. Giffard-Mena I, Charmantier G, Grousset E, Aujoulat F, Castille R. Digestive tract ontogeny of Dicentrarchus labrax: implication in osmoregulation. Dev Growth Differ. (2006) 48:139-51. doi: 10.1111/j.1440-169X.2006.00852.x

129. Miwa S, Yamano K, Inui Y. Thyroid hormone stimulates gastric development in flounder larvae during metamorphosis. J Exp Zool. (1992) 261:42430. doi: 10.1002/jez.1402610409

130. Huang L, Schreiber AM, Soffientino B, Bengtson DA, Specker JL. Metamorphosis of summer flounder (Paralichthys dentatus): thyroid status and the timing of gastric gland formation. J Exp Zool. (1998) 280:41320. doi: 10.1002/(SICI)1097-010X(19980415)280:6<413::AID-JEZ5>3.0. $\mathrm{CO} ; 2-\mathrm{Q}$

131. Rønnestad I, Dominguez RP, Tanaka M. Ontogeny of digestive tract functionality in Japanese flounder, Paralichthys olivaceus studied by in vivo microinjection: $\mathrm{pH}$ and assimilation of free amino acids. Fish Physiol Biochem. (2000) 22:225-35. doi: 10.1023/A:1007801510056

132. Matsuda H, Mullapudi ST, Zhang Y, Hesselson D, Stainier DYR. Thyroid hormone coordinates pancreatic islet maturation during the zebrafish larvalto-juvenile transition to maintain glucose homeostasis. Diabetes. (2017) 66:2623-35. doi: 10.2337/db16-1476

133. Roman-Padilla J, Rodriguez-Rua A, Manchado M, Hachero-Cruzado I. Molecular characterization and developmental expression patterns of 
apolipoprotein A-I in Senegalese sole (Solea senegalensis Kaup). Gene Expr Patterns. (2016) 21:7-18. doi: 10.1016/j.gep.2016.05.003

134. Kyle HM. II.-The asymmetry, metamorphosis and origin of flatfishes. Philosophical Transactions of the Royal Society of London. Series B, Containing Papers of a Biological Character. (1923) 211:75129. doi: $10.1098 /$ rstb. 1923.0002

135. Friedman M. The evolutionary origin of flatfish asymmetry. Nature. (2008) 454:209-12. doi: 10.1038/nature07108

136. Friedman M. Explosive morphological diversification of spinyfinned teleost fishes in the aftermath of the end-Cretaceous extinction. Proc R Soc B. (2010) 277:1675-83. doi: 10.1098/rspb.2009 .2177

137. Schreiber AM. Asymmetric craniofacial remodeling and lateralized behavior in larval flatfish. J Exp Biol. (2006) 209:610-21. doi: 10.1242/jeb.02056

138. Sæle $\varnothing$, Solbakken JS, Watanabe K, Hamre K, Pittman K. The effect of diet on ossification and eye migration in Atlantic halibut larvae (Hippoglossus hippoglossus L.). Aquaculture. (2003) 220:683-96. doi: 10.1016/S0044-8486(02)00584-7

139. Bao B, Ke Z, Xing J, Peatman E, Liu Z, Xie C, et al. Proliferating cells in suborbital tissue drive eye migration in flatfish. Dev Biol. (2011) 351:2007. doi: 10.1016/j.ydbio.2010.12.032

140. Peterson JR, De La Rosa S, Eboda O, Cilwa KE, Agarwal S, Buchman SR, et al. Treatment of heterotopic ossification through remote ATP hydrolysis. Sci Transl Med. (2014) 6:255ra132. doi: 10.1126/ scitranslmed.3008810

141. Suzuki T, Washio Y, Aritaki M, Fujinami Y, Shimizu D, Uji S, et al. Metamorphic pitx2 expression in the left habenula correlated with lateralization of eye-sidedness in flounder. Dev Growth Differ. (2009) 51:797808. doi: 10.1111/j.1440-169X.2009.01139.x

142. Concha ML, Wilson SW. Asymmetry in the epithalamus of vertebrates. $J$ Anat. (2001) 199:63-84. doi: 10.1017/S0021878201008329

143. Bohnsack BL, Kahana A. Thyroid hormone and retinoic acid interact to regulate zebrafish craniofacial neural crest development. Dev Biol. (2013) 373:300-9. doi: 10.1016/j.ydbio.2012.11.005

144. Gomes AS, Alves RN, Stueber K, Thorne MA, Smáradóttir H, Reinhard R, et al. Transcriptome of the Atlantic halibut (Hippoglossus hippoglossus). Mar Genomics. (2014) 18:101-3. doi: 10.1016/j.margen.2014.0 7.005

145. Shao C, Bao B, Xie Z, Chen X, Li B, Jia X, et al. The genome and transcriptome of Japanese flounder provide insights into flatfish asymmetry. Nat Genet. (2016) 49:119. doi: 10.1038/ng.3732

146. Chen S, Zhang G, Shao C, Huang Q, Liu G, Zhang P, et al. Wholegenome sequence of a flatfish provides insights into $\mathrm{ZW}$ sex chromosome evolution and adaptation to a benthic lifestyle. Nat Genet. (2014) 46:25360. doi: $10.1038 /$ ng. 2890
147. Alves RN, Gomes AS, Stueber K, Tine M, Thorne MA, Smáradóttir H, et al. The transcriptome of metamorphosing flatfish. BMC Genomics. (2016) 17:413. doi: 10.1186/s12864-016-2699-x

148. Louro B, Marques JP, Manchado M, Power DM, Campinho MA. Sole head transcriptomics reveals a coordinated developmental program during metamorphosis. Genomics. (2019). doi: 10.1016/j.ygeno.2019.04.011. [Epub ahead of print].

149. Prunet P, Boeuf G, Bolton JP, Young G. Smoltification and seawater adaptation in Atlantic salmon (Salmo salar): plasma prolactin, growth hormone, and thyroid hormones. Gen Comp Endocr. (1989) 74:35564. doi: 10.1016/S0016-6480(89)80031-0

150. Higgs DA, Fagerlund UHM, Eales JG, McBride JR. Application of thyroid and steroid hormones as anabolic agents in fish culture. Comp Biochem Physiol B. (1982) 73:143-76. doi: 10.1016/0305-0491(82)90206-1

151. Ojima D, Iwata M. The relationship between thyroxine surge and onset of downstream migration in chum salmon Oncorhynchus keta fry. Aquaculture. (2007) 273:185-93. doi: 10.1016/j.aquaculture.2007.10.024

152. Specker JL, Brown CL, Bern HA. Asynchrony of changes in tissue and plasma thyroid hormones during the parr-smolt transformation of coho salmon. Gen Comp Endocr. (1992) 88:397-405. doi: 10.1016/0016-6480(92)90234-B

153. Lorgen M, Casadei E, Król E, Douglas A, Birnie MJ, Nilsen TO, et al. Functional divergence of type 2 deiodinase paralogs in the atlantic salmon. Curr Biol. (2015) 25:936-41. doi: 10.1016/j.cub.2015.01.074

154. McCormick SD, Björnsson BT. Physiological and hormonal differences among Atlantic salmon parr and smolts reared in the wild, and hatchery smolts. Aquaculture. (1994) 121:23544. doi: 10.1016/0044-8486(94)90023-X

155. Björnsson BT, Stefansson SO, McCormick SD. Environmental endocrinology of salmon smoltification. Gen Comp Endocr. (2011) 170:290-8. doi: 10.1016/j.ygcen.2010.07.003

156. Kitano J, Lema SC, Luckenbach JA, Mori S, Kawagishi Y, Kusakabe $\mathrm{M}$, et al. Adaptive divergence in the thyroid hormone signaling pathway in the stickleback radiation. Curr Biol. (2010) 20:2124-30. doi: 10.1016/j.cub.2010.10.050

Conflict of Interest Statement: The author declares that the research was conducted in the absence of any commercial or financial relationships that could be construed as a potential conflict of interest.

Copyright (๑) 2019 Campinho. This is an open-access article distributed under the terms of the Creative Commons Attribution License (CC BY). The use, distribution or reproduction in other forums is permitted, provided the original author(s) and the copyright owner(s) are credited and that the original publication in this journal is cited, in accordance with accepted academic practice. No use, distribution or reproduction is permitted which does not comply with these terms. 